\title{
Buying and Selling Behavior of Individual Investors in Option-like Securities
}

\author{
Philipp Schmitz and Martin Weber*
}

October 5, 2007

\begin{abstract}
We analyze the trading behavior of individual investors in option-like securities, namely bankissued warrants, and thus expand the growing literature of investors behavior to a new kind of securities. A unique data set from a large German discount broker gives us the opportunity to analyze the trading behavior of 1,454 investors, making 89,958 transactions in 6,724 warrants on 397 underlyings. In different logit regression, we make use of the facts that investors can speculate on rising and falling prices of the underlying with call and put warrants and that we also have information about the stock portfolios of the investors. We report several facts about the trading behavior of individual investors in warrants that are consistent with the literature on the behavior of individual investors in the stock market. The warrant investors buy calls and sell puts if the price of the underlying has decreased over the past trading days and they sell calls and buy puts if the price of the underlying has increased. That means, the investors follow negative feedback trading strategies in all four trading categories observed. In addition, we find strong evidence for the disposition effect for call as well as put warrants. The trading behavior is also influenced if the underlying reaches some exceptionally prices, e.g. highs, lows or the strike price. We show that hedging, as one natural candidate to buy puts, does not play an important role in the market for bank-issued warrants. The probability to buy calls is positively related to the holding of the underlying in the portfolio, meaning that investors tend to leverage their stock positions, while the relation between put purchases and portfolio holdings of the underlying is negative. Differences in the trading behavior in warrants with stock market indexes or single stocks as underlings are small.
\end{abstract}

Keywords: Individual Investors, Trading Behavior, Negative Feedback Trading, Disposition Effect, Bank-issued Warrants

JEL Classification Code: G1

*Philipp Schmitz is from the Chair of Banking and Finance, University of Mannheim, L 5, 2, 68131 Mannheim. E-Mail: schmitz@bank.BWL.uni-mannheim.de. Martin Weber is from the Chair of Banking and Finance, University of Mannheim, L 5, 2, 68131 Mannheim and CEPR, London. E-Mail: weber@bank.BWL.uni-mannheim.de. We would like to thank Mathijs Cosemans, seminar participants at the University of Mannheim, and participants of the 14th Annual Meeting of the German Finance Association in Dresden for valuable comments and insights. Financial Support from the Deutsche Forschungsgemeinschaft (DFG) is gratefully acknowledged. 


\title{
Buying and Selling Behavior of Individual Investors in Option-like Securities
}

\begin{abstract}
We analyze the trading behavior of individual investors in option-like securities, namely bankissued warrants, and thus expand the growing literature of investors behavior to a new kind of securities. A unique data set from a large German discount broker gives us the opportunity to analyze the trading behavior of 1,454 investors, making 89,958 transactions in 6,724 warrants on 397 underlyings. In different logit regression, we make use of the facts that investors can speculate on rising and falling prices of the underlying with call and put warrants and that we also have information about the stock portfolios of the investors. We report several facts about the trading behavior of individual investors in warrants that are consistent with the literature on the behavior of individual investors in the stock market. The warrant investors buy calls and sell puts if the price of the underlying has decreased over the past trading days and they sell calls and buy puts if the price of the underlying has increased. That means, the investors follow negative feedback trading strategies in all four trading categories observed. In addition, we find strong evidence for the disposition effect for call as well as put warrants. The trading behavior is also influenced if the underlying reaches some exceptionally prices, e.g. highs, lows or the strike price. We show that hedging, as one natural candidate to buy puts, does not play an important role in the market for bank-issued warrants. The probability to buy calls is positively related to the holding of the underlying in the portfolio, meaning that investors tend to leverage their stock positions, while the relation between put purchases and portfolio holdings of the underlying is negative. Differences in the trading behavior in warrants with stock market indexes or single stocks as underlings are small.
\end{abstract}

Keywords: Individual Investors, Trading Behavior, Negative Feedback Trading, Disposition Effect, Bank-issued Warrants

JEL Classification Code: G1 


\section{Introduction}

As detailed data sets about individuals' transactions from discount and online brokers became available in the late 1990's, knowledge about the trading behavior of individual investors has increased substantially. Most of the existing empirical studies analyze the behavior of investors in the stock market. Fewer authors look at transactions in mutual funds. Findings for investors trading derivatives are very rare.

Due to a unique transaction data set from a large German online broker, we are able to extend the existing literature by analyzing the buying and selling behavior of individual investors in a further kind of securities: bank-issued warrants. Bank-issued warrants (warrants hereafter) securitize the right, but not the obligation, to buy (call) or sell (put) a certain amount of the underlying security for a previously specified price up to (American-style warrant) or on (European-style warrant) a previously specified maturity date. The payoff structure of those warrants is the same as for plain-vanilla options, but they differ from options in some institutional characteristics. First, the contract size is much smaller. Typically, the owner of one warrant has the right to buy or sell one-tenth or one-hundredth of the underlying with this contract. Secondly, these typical retail banking products are issued by financial institutions only. That makes short-selling (i.e. writing) warrants impossible for individual investors, so no margin accounts are required. Thirdly, transaction fees for small trading volumes are lower for warrants than for options at all German online brokers. Fourthly, warrants legally are obligations from the issuer directly to the owner. There is no clearing institution as in the option market. Since all issuers in the warrant market are financial institutions this default risk should be small and have only minor price impacts.

Especially the first three points might explain why those products are much more popular than options for individual investors with low money to invest. The market for warrants grew rapidly since the first issuance of a stand-alone warrant ${ }^{1}$ in 1988. In Germany, nearly 50.000 different warrants were listed in December of 2006 and the trading volume was more than 1,4 Billion euros in that month. ${ }^{2}$

\footnotetext{
${ }^{1}$ Traditional warrants are usually issued in combination with a bond (so called warrant-linked bond). They give the warrant holder the right, but not the obligation, to acquire shares of the issuing company and thus are always call warrants.

${ }^{2}$ See DDI (2007). For more details on the international markets for bank-issued warrants, see Glaser and Schmitz (2007).
} 
Despite the tremendous attention these securities have received in the last 10 to 15 years in Europe, Asia and Australia, little is known about what actually makes investors trade these securities. We fill this gap by analyzing 89,958 transactions of 1,454 individual investors in 6,724 warrants with 380 stocks and 17 stock market indexes as underlyings. The structure of the warrant market, for example the existence of call and put warrants as well as the possibility to invest in a whole index ${ }^{3}$, allows us to analyze the trading behavior in several more dimensions than if one would look at stock market transactions. For example, instead of comparing, in the absence of short selling possibilities, purchases of stocks with sales of stocks to analyze the buying behavior ${ }^{4}$, we can compare purchases of call warrants with purchases of put warrants. In addition, investors cannot only trade warrants on single stocks, but also invest in whole indexes by purchasing warrants with those indexes as underlyings. We relate our study to that of Grinblatt and Keloharju (2001b), but use transactions from a different type of security and extend the methodology in several ways. Furthermore, we are able to link the transaction behavior in the warrant market with the stock market transactions of these investors.

We report several facts about the trading behavior of individual investors in warrants that are consistent with the literature on the behavior of individual investors in the stock market. The warrant investors buy calls and sell puts if the price of the underlying has decreased over the previous trading days and they sell calls and buy puts if the underlying has increased. This means the investors follow negative feedback trading strategies in all four of the observed trading categories. In addition, we find strong evidence for the disposition effect for call as well as put warrants. The trading behavior is also influenced if the underlying reaches some exceptional prices, e.g. highs, lows or the strike price. We also show that hedging (as one natural candidate to buy puts) does not play an important role in the market for bank-issued warrants. The probability to buy calls is positively related to the holding of the underlying in the portfolio, meaning that investors tend to leverage their stock positions, while the relation between put purchases and portfolio holdings of the underlying is negative. Differences in the trading behavior in warrants with stock market indexes or single stocks as underlyings are small.

We proceed as follows: In Section 2, we give a categorized overview over the related

\footnotetext{
${ }^{3}$ Exchange traded funds did not exist in Germany during our observation period.

${ }^{4}$ See Grinblatt and Keloharju (2001b).
} 
literature concerning the trading behavior of individual investors. Our data is described in detail in Section 3. Section 4 explains the methodology used and provides results for the buying and selling behavior separately. A conclusion is provided in Section 5.

\section{$2 \quad$ Related Literature}

\subsection{Individual Investors' Behavior in the Stock Market}

The examination of private investor data at the individual level already began in the 1970's. In a whole series of papers based on brokerage account data and a large survey, Cohn, Lease, Lewellen, and Schlarbaum ${ }^{5}$ were the first to describe several stylized facts about the actual trading behavior of individual investors. Besides showing a wide variety of demographic facts about individual investors, they are able to infer investors' attitudes towards risk by looking at the self-reported overall portfolio composition of the investors. They also report the dependence of the investment style of the investors on age, income, and gender; denying the influence of other demographics. They also find that individual investors show some skill when it comes to security selection, but after correcting for transaction costs, the net returns realized are indistinguishably different from passive investment strategy returns. After those early studies, it took about 20 years until the trading behavior of individual investors went back into the spotlight of financial research. This attention is mainly due to the emergence of different data sets from discount and online brokers, first from the US and then from around the world.

When it comes to analyzing determines transaction behavior, it is essential to differentiate between buying and selling. This is because the motives for both groups of transactions might be different. As Barber and Odean (2007) point out that a problem in the decision process which stocks to buy and sell is the bounded rationality of decision makers with cognitive and temporal limits. Individual investors have to choose from a wide range of investment opportunities if they want to purchase a stock, but are limited

\footnotetext{
${ }^{5}$ They published several papers in mixed author combinations, i.e. Lease, Lewellen, and Schlarbaum (1974), Cohn, Lewellen, Lease, and Schlarbaum (1975), Lewellen, Lease, and Schlarbaum (1977), Schlarbaum, Lewellen, and Lease (1978a), and Schlarbaum, Lewellen, and Lease (1978b).
} 
to the stocks they hold in their portfolio if they consider to sell. ${ }^{6}$ The authors show that individual investors' buying decisions on the stock market are more attention-based than their selling behavior. On the other hand, motives for a sale of stocks may possibly be rebalancing or liquidity needs, but also a valuation of the asset in comparison to the purchase price might influence the decision to sell a stock. Although most of the following studies look at purchases as well as sales, we provide results for determinants of purchase transactions first, and we look at sale transactions in the next section.

\subsubsection{Buying Behavior}

A large number of authors test whether past returns influence the trading decisions of individual investors. Barber and Odean (2007) show that individual investors are net buyers of stocks with high absolute returns. There are mixed results concerning the direction of the influence of returns on the propensity of individual investors to buy stocks. Two competing theories emerged: positive vs. negative feedback trading. While momentum investors buy stocks after their value increased, contrarians tend to buy stocks that have lost value prior to the purchase. For short horizons, most authors find a negative relation between past days returns and net buying of individual investors. This short-term contrarian buying behavior is reported for several markets, including the US (Griffin, Harris, and Topaloglu (2003)), Finland (Grinblatt and Keloharju (2000) and Grinblatt and Keloharju (2001b)), Korea (Choe, Kho, and Stulz (1999)), and Australia (Jackson (2003)). Only for Germany, Dorn, Huberman, and Sengmueller (2007) find a positive relation for retail investor buying and returns the day before, while the return two days before is significantly negatively related to net purchases. For longer horizons (4 month to 2 years), several authors find positive feedback buying in different stock markets. A positive correlation of purchases and past returns was found in the US by Odean (1999) and Barber, Odean, and Zhu (2003), in China by Chen, Kim, Nofsinger, and Rui (2005), and in Japan by Kim and Nofsinger (2002). Barber, Odean, and Strahilevitz (2004) show that stocks that were sold for a gain or have decreased in value since they were previously sold are more likely to be repurchased by an individual investor. Furthermore, in sequential round-trip trades, investors tend to buy additional shares if the price of the stock is lower than the initial price when they first bought the stock.

\footnotetext{
${ }^{6}$ Individual investors are reluctant to sell stocks short. Whether this is due to regulatory restrictions, higher transaction costs or other reasons is not yet obvious.
} 
Besides past returns, additional determinants of the buying behavior are analyzed, most elaborated by Grinblatt and Keloharju (2001b). They find influence of several demographics (e.g. age and gender) on the propensity to buy stocks. In addition, volatility and monthly highs and lows of the stocks also influence the buying behavior. Kumar and Dhar (2002) find that 3-month lows can influence the buying decision, especially for contrarian investors. Grinblatt and Keloharju (2001a) show that Finnish investors are most likely to buy stocks from firms which have their headquarter nearby, also known as home bias.

\subsubsection{Selling Behavior}

Similar to the buying behavior, the selling behavior of individual investors is influenced by demographics, volatility and prominent prices like highs and lows (see Grinblatt and Keloharju (2001b), Kumar and Dhar (2002), and Chen, Kim, Nofsinger, and Rui (2005)). The strongest influence on the selling decision have past returns. In contrast to the positive feedback buying (i.e. buying after high past returns over longer horizons) in the long-run, the same studies find negative feedback trading when it comes to selling stocks (see Odean (1999), Kim and Nofsinger (2002), and Barber, Odean, and Zhu (2003)). They report that not only purchases but also sales are positively influenced by high past returns. This is contrarian behavior. The same holds for short-term feedback trading. Investors tend to sell stocks if the past days' returns are positive (see Griffin, Harris, and Topaloglu (2003) and Jackson (2003)).

This return pattern is consistent with the disposition effect. This effect was first analyzed by Schlarbaum, Lewellen, and Lease (1978b) and Shefrin and Statman (1985). The tendency to sell winners too early and hold on to losing stocks for an unusually long period of time was documented for individual investors in several markets. The disposition effect exists in the US (Odean (1998)), Finland (Grinblatt and Keloharju (2001b)), Israel (Shapira and Venezia (2001)), China (Chen, Kim, Nofsinger, and Rui (2005)), and Germany (Weber and Welfens (2006)). As Odean (1998) points out, it is hard to disentangle investors' selling behavior based on beliefs of mean reversion in future stock prices (no matter whether their beliefs are right or wrong) from the behavior according to their reluctance to realize losses. Both hypotheses would predict that investors more readily sell stocks that have risen in the past. In an experimental setting with and without an automatic selling condition, Weber and Camerer (1998) show that the disposition effect 
is much weaker if stocks are sold automatically after every period, and that investors falsely believe in mean reversion of stock prices although they should know about the trending behavior of the stocks. Badrinath and Lewellen (1991), Odean (1998), and Grinblatt and Keloharju (2004) show that the disposition effect is reversed in December, which is due to tax-motivated selling, according to the authors.

\subsection{Individual Investors' Behavior in Derivative Markets}

In comparison to the findings for the individuals investors' trading behavior of in the stock market, little is known about how those investors trade derivative products. Lakonishok, Lee, Pearson, and Poteshmann (2007) show that non-market maker investors in the US have more open interest in written option positions than in long positions for calls and puts. If the investors buy options to open a new position, they purchase four times more calls than puts. They also show that higher option market trading activity is positively correlated with past returns and volatility, and negatively correlated with book-to-market ratios. In addition they report that investors open and close long and short call positions if past week's return is positive and write puts as well as close bought and written put positions if the past returns are negative. Different results are obtained by Schmitz, Glaser, and Weber (2007). Looking at the difference in the holdings of call and put warrants, one can infer that high (low) returns in the past two days change the aggregated holdings in put (call) positions. This result is along the same lines as the short-term negative feedback trading results from the stock market. Bauer, Cosemans, and Eichholtz (2007) compare the trading success of individual investors engaged in derivatives trading with the results of non-derivative traders. Derivatives traders trade more and thereby underperform the market by a substantial amount. Heath, Huddart, and Lang (1999) and Poteshman and Serbin (2003) show that the (rational and irrational) exercise behavior in employee stock options and plain-vanilla options, respectively, is related to past returns. While employees typically exercise their options after the price of the underlying has risen in the past month but fallen over longer horizons, option traders tend to utilize their right to exercise these derivatives after high returns and if the underlying is near its highest price of the past year. 


\section{Description of the Data}

Our analysis is based on the individual transactions in bank-issued warrants on single stocks and indexes of individual investors, who trade with a large German online broker. The data set contains detailed information on the transactions (investor ID, trading date, warrant ID, type of warrant (call or put), type of transaction (purchase or sale), transaction price, number of warrants traded, transaction costs, and currency), the warrants (warrant ID, name of the underlying, strike price, conversion ratio, and maturity date), and self reported demographic information of the investors (investor ID, age, gender, income, investment experience, and investment strategy). Transaction information starts at the beginning of 1997 and ends in the middle of April 2001. Information on the prices of the underlyings is obtained from Datastream.

1,454 investors trade 6,724 different warrants on 397 different underlyings accounting for 89,958 transactions. Table 1 shows that most of the transactions (55\%) are from warrants on indexes, despite the fact that there are only 17 different indexes as underlyings, when compared to 380 different stocks. This fact can be predominantly attributed to the high number of transactions in warrants on the main German stock index DAX (see Table 2). Another observation is that the investors make more purchases (55\%) than sales. The portion of transactions in call and put warrants is remarkable. Only $23 \%$ of all transactions are in put warrants. If one looks at the portion of calls and puts in transactions on single stocks, less than $6 \%$ of the transactions are in put warrants. In contrast, transactions in call and put warrants on indexes are much more even distributed $(45 \%$ puts).

To describe the investors in the market, we use three sets of variables. First we provide descriptive statistics for the trading in warrants itself (see Panel A of Table 3). The average investor makes 55 warrant transactions. While half of the investors traded 18 times or less, some of the investors are involved in heavy trading. The individual with the most transactions traded 1,461 times during the 1,080 trading days in our sample period. This number does not include intraday trading since we netted all purchases and all sales in one warrant during one trading day, from one investor separately.

To calculate the actual return and holding period per trade or per investor, we first define round-trip trades as all trades in one specific warrant made by one specific investor 
from the opening of a new position, until it is completely closed again. Thus, a round-trip trade always starts with a purchase and ends in a sale, while the number of the specific warrant is zero at the beginning and end, but strictly positive in-between. Otherwise, a round-trip trade could include several purchases and sales in a mixed order. ${ }^{7}$ We calculate the net return of a round-trip trade as

$$
\text { return }=\frac{\sum_{j=1}^{s} \text { number of warrants } \text { sold }_{j} \cdot \text { sale price }_{j}-t c_{j}}{\sum_{i=1}^{p} \text { number of warrants bought }_{i} \cdot \text { purchase price }_{i}-t c_{i}}-1
$$

where tc are the trade-specific transaction costs, and $\mathrm{p}$ and $\mathrm{s}$ are the total number of purchases and sales involved in a round-trip trade. For example, a purchase of 1,000 warrants for a price of $0.90 €(\mathrm{tc}=10 €)$, a purchase of another 1,000 warrants for the price of $1.12 €(\mathrm{tc}=10 €) 10$ trading days later and the sale of 2,000 warrants for $1.06 €$ $(\mathrm{tc}=20 €) 20$ trading days after the initial purchase would count for 1 round-trip trade with a return of

$$
\frac{2,000 \cdot 1.06-20}{1,000 \cdot 0.90-10+1,000 \cdot 1.12-10}-1=0.05
$$

For the return per investor $\mathrm{p}$ and $\mathrm{s}$ are the total number of round-trip purchases and sales during the entire sample period. On average, a warrant investor receives $1.2 \%$ return on the invested money over the sample period of over four years.

To put this number into perspective, one needs to know how long the investors hold the warrants. To receive the average duration of a warrant position in the portfolio, we simply calculate the average number of trading days the warrants within the position remain in the portfolio. For the example mentioned above, the holding period would be

$$
\frac{1,000 \cdot 20+1,000 \cdot 10}{2,000}=15
$$

trading days. An average investor holds his warrants for 69 days, while half of the investors hold their warrants for 43 days or less. ${ }^{8}$ In addition we find that the median transaction volume is $1,723 €$ and that investors typically trade warrants with a time to maturity of 108.35 trading days.

The second set of variable are from the stock portfolios of our warrant traders. In Panel B of Table 3, we show that the median warrant investor trades stocks 74 times

\footnotetext{
${ }^{7}$ Similar procedures were used by Shapira and Venezia (2001) and Feng and Seasholes (2005).

${ }^{8}$ By only looking at round-trip trades, we exclude some warrants that were already in the portfolio at the beginning or still in the portfolio at the end of our observation period. In contrast to stock investments, the sampling bias should be small, because the holding period for warrants is much lower (the median holding period per warrant is 9 days) than for stocks and thus only a few warrant transactions are neglected.
} 
during the sample period, holds five stocks in his portfolio that are worth $14,743 €$. He receives a monthly return of $0.4 \%$ bearing a monthly standard deviation of his portfolio return of $12.4 \%$, while the monthly return and standard deviation for the DAX index in the same time was $1.7 \%$ and $2.1 \%$, respectively.

The third set of information concerns self-reported demographic and investment aim information of the investors. The age is measured as the actual years since birth at the beginning of 1997, gender is a dummy variable indicating whether the investor is a male (1) or female (0). For experience and income, investors were asked to state their experience in trading securities and monetary income on different scales, respectively. The experience categories were 0-5 years, 5-10 years, 10-15 years, and greater than 15 years, while for income the following categories could be chosen: 0-25,564 €, 25,565-51,129 €, $51,130-76,693 €, 76,694-102,258 €$, and over $102,259 €{ }^{9}$ We used the midpoint of the categories, and 17,5 years and $115,041 €$ for the last categories respectively. In another question, the investors were asked to state their main goal of securizy investing, given a choice of six different categories. If investors state that their strategy is to save for retirement, the dummy retirement is 1 ; if not it is 0 . If high risk speculating is the aim of an investor, the dummy high risk is 1 and otherwise it is 0 . The median investor is 38 years of age at the beginning of our sample period, has investment experience of 7.5 years and an income of little more than $38,000 €$ (see Panel $\mathrm{C}$ of Table 3). Only $4 \%$ of all warrant investors are female and only $3 \%$ state that their main goal for opening the online broker account is saving for retirement, while $19 \%$ say that they pursue a high risk strategy. The remarkable portion of $72 \%$ held a mutual fund at least once during the sample period.

\section{Methodology and Results}

The main focus of our paper is to show what the determinants of the buying and selling behavior of individual investors in the market for warrants are. Is the trading behavior similar to trading in other kind of securities? In addition, the structure of the market for warrants gives us the opportunity to apply new methods to investigate the trading behavior. We do this for purchases and sales of warrants separately, and further divide

\footnotetext{
${ }^{9}$ Originally the income categories were stated in Deutsche Mark (DEM). We converted the values with the official DEM/EUR exchange rate of 1.95583 DEM $=1$ EUR.
} 
the sample into calls and puts and warrants on stock market indexes and single stocks.

\subsection{Determinants of the Buying Behavior}

In the absence of short selling possibilities, the decision to sell a security differs from the decision to buy, because the set of trading opportunities is restricted to those securities one holds in his portfolio when it comes to selling. The set of alternatives is fairly small in most cases. If someone decides to purchase a security, the set of opportunities is huge, meaning every security traded on all markets, at least theoretically. To shrink the number of alternatives, people may use heuristics. As pointed out by Barber and Odean (2007), investors buy stocks that recently caught their attention.

To have a starting point to analyze what makes investors buy warrants, we assume that the warrants an investor trades are the set of alternatives he can choose from. In step one, we defined a dummy variable that is 1 if an investor purchases a specific warrant on a trading day, and otherwise it is 0 for trading days on which this specific warrant is tradeable (i.e. the time between the date of issue and the maturity date of the warrant). This procedure is done for every warrant that a specific investor traded at least once during our sample period. This variable is then the dependent variable in a logit regression. We apply different regressions for call and put warrant purchases, and further subdivide those two categories into purchases in index and single stock warrants.

Related studies concerning the trading behavior of individual investors in the stock market all find a strong influence of past returns on the decision to trade a stock. Because we also want to test whether previous returns and variability of the underlyings influence the trading behavior in warrants, we define 11 non-overlapping historical returns. They are named $\operatorname{ret}^{u}[\bullet]$, where the $\bullet$ stands for the time period before the observation date. The superscript $u$ indicates those variables concerning the returns of the underlying. To see whether past variability of the stock returns has an influence on the trading behavior, we include the average of the squared net-returns over the last 60 trading days into our regression analysis $\left(\left(\text { avg_ret }^{2}\right)^{u}[-59 ; 0]\right)$. To better compare our results with those of Grinblatt and Keloharju (2001b), we chose the same time periods as they did. The rationale for looking at the price of the underlying instead of the price of the warrant is that warrants are derivatives of their underlings. The price of the warrant is mainly 
determined by the price of the underlying. ${ }^{10}$ Thus, the investor needs to have an opinion about future price changes of the underlying, rather than of the warrant itself. We do not consider market-adjusted returns, because in our opinion investors look at the raw returns of the underlying rather than calculating abnormal returns. In addition, more than half of the warrants have indexes as an underlying, which would make a market adjustment a fairly useless exercise.

We further test whether some exceptional prices change the propensity to buy warrants. One natural candidate for such a price is the strike price of the warrant. Taking into account the strike price as a reference point, we define a variable which we call modified moneyness (mod. moneyness). It is calculated as

$$
\text { mod. moneyness } s_{t}=\frac{K+\left(S_{t}-K\right)}{K} \quad \text { for call warrants }
$$

and

$$
\text { mod. moneyness } s_{t}=\frac{K+\left(K-S_{t}\right)}{K} \quad \text { for put warrants }
$$

where $S_{t}$ is the price of the underlying in $\mathrm{t}$ and $\mathrm{K}$ ist the strike price of the warrant, resulting in a measure that defines the relative distance of the actual price of the underlying to the strike price of a warrant in a symmetric way for call and put warrants. A value greater than one indicates that a call as well as a put warrant is in-the-money, i.e. the price of the underlying is higher (lower) than the strike price for call (put) warrants, meaning that its intrinsic value is positive. We also generate dummies with the value 1 if the mod. moneyness is

(i) $0.98 \leq$ mod. moneyness $t_{t}<1$ and mod. moneyness t $-1_{1}<0.98$ (near_strike_right) or

(ii) $1<\bmod$. moneyness $s_{t} \leq 1.02$ and mod. moneyness $t_{t-1}>1.02$ (near_strike_wrong) or (iii) $1 \leq$ mod. moneyness $s_{t}<1.02$ and mod. moneyness $s_{t-1}<1$ (cross_strike_right) or (iv) $0.98<\bmod$. moneyness $s_{t} \leq 1$ and mod. moneyness $s_{t-1}>1$ (cross_strike_wrong).

These variables measure whether the price of the underlying approaches the strike price without crossing it in the direction desired (i), that means a positive jump of the price of the underlying coming close to the strike price for call warrants and a declining

\footnotetext{
${ }^{10}$ Since besides the price of the underlying, other factors determine the value of warrants, i.e. volatility and the riskfree rate, betting on changes in those variables might also be a motive to trade those securities. But for example, a pure speculation on the volatility of the underlying requires the simultaneous purchase of call and put warrants (with different strike prices) on the same underlying (so called straddles). We do not find such strategies in the portfolios of the individual investors. In addition, sensitivities of the price of a warrant to changes in these determinants are much smaller than to changes in the price of the underlying.
} 
price for put warrants, or disliked (ii) by the holder of the warrant and whether the price of the underlying goes from out-of-the-money to in-the-money (iii) or the other way around (iv). Since extreme prices also have an influence on the trading decision ${ }^{11}$, we test for additional reference prices associated with the price of the underlying. We generated the dummies d_ref_max ${ }^{u}[-19 ;-1]$, d_ref_min ${ }^{u}[-19 ;-1]$, and d_ref_avg ${ }^{u}[-19 ;-1]$ that are 1 if the price of the underling is above the maximum or below the minimum or above the average price of the underlying of the 19 days before respectively. ${ }^{12}$

An additional dummy variable is 1 if the investor already holds the underlying of the warrant itself in his portfolio. This gives us a hint whether calls are used to leverage the position in the underlying, or whether puts are used to hedge the underlying, as it is often mentioned as a strategy with derivatives in different textbooks. ${ }^{13}$ In Table 4, we report the number of purchases of warrants when the underlying is in the portfolio of the investor. Warrants are purchased 2,288 times while the underlying is in the portfolio. This is the case for 2,201 calls and only 87 puts. The last number, especially in comparison to that for calls, makes it unlikely that hedging is the main motive for trading warrants. For only $0.66 \%$ of all put purchases is the underlying actually in the portfolio of the investor. But since an index cannot be held by an investor, we also report the ratio of put purchases when the warrant is in the portfolio to the number of purchases in warrants on single stocks. In $7.26 \%$ of the cases where a put warrant on a stock is purchased, the respective stock is in the portfolio of the investor. But in every case, the investors hold relatively more underlyings of call than put warrants.

\footnotetext{
${ }^{11}$ See Grinblatt and Keloharju (2001b) for stocks and Poteshman and Serbin (2003) for options.

${ }^{12}$ We also generated dummies for one year horizon maximum and minimum prices, since Poteshman and Serbin (2003) report more exercises in options if the underlying is near an one year high. We find some influence of the one year maximum price and no influence of the one year minimum price. Due to the general market movement of the underlyings, prices are rarely at their one year minimum. Since the holding period for warrants is low, we believe the shorter horizon of 19 trading days is more appropriate to measure highs and lows of the underlyings.

${ }^{13}$ Lakonishok, Lee, Pearson, and Poteshmann (2007) analyze position opening option transactions from different investor groups in the US and find that individual investors rarely open positions with long puts. They follow that hedging is an unimportant strategy for individuals in the option market. In a survey of individual investors in Germany, only $8 \%$ state that protecting stocks through a purchase of a warrant might be a motive to purchase a put warrant (see Klotz (2004)).
} 


\subsubsection{Call Purchases}

In the second column of Table 5, the coefficients and robust p-values for a logit regression (with the buying dummy described above based on purchases in call warrants on all underlyings) are reported. By looking at the past returns of the underlying, we find that a significantly negative relationship exists between those returns and the decision to buy a call warrant. It means that the probability that the investors buy a call is higher if past returns of the underlying are negative in the short-run. This relation turns around for returns that occured longer ago. The influence of past returns is stronger for shortterm returns than for returns further in the past. These results are similar to the results found for individual investors in the stock market. The warrant investors buy calls on negative feedback from returns on both the same and the prvious trading days. Over longer horizons, they are positive feedback traders, since positive returns influence their probability to buy calls positively. In addition, we find a strong positive effect of the average squared return over the last 60 trading days on the likelihood to buy a call.

The modified moneyness of call warrants does not seem to have an influence on the trading behavior of individual investors. But if we consider the strike price of the warrants as a reference price and look at the dummy variables measuring whether the price of the underlying comes close to or crosses this strike price, we find that all of these dummies positively influence the decision to buy call warrants. This means investors buy call warrants if the price of the underlying is approaching or crossing the strike price of these warrants, no matter whether this happens in the right (upward moves of the underlying for calls and decreasing prices for puts) or wrong direction. It might be the case that investors focus on the strike price and that approaching or crossing this price creates attention. Furthermore, Barber and Odean (2007) show that attention (although measured differently) can drive the decision to buy a security.

Similar results are obtained for the maximum and minimum prices of the underlying. If the price of the underlying is above its maximum or below its minimum price of the last 19 trading days, the call warrants are more likely to be bought by the individual investors. Given the results concerning the influence of past returns, it is not surprising that people buy below the minimum price; since this is in line with contrarian behavior. But the buying above the 19-day high is counterintuitive, since this seems to favor positive feedback trading. The investors seem to buy at both extreme prices but low prices have 
a stronger effect. Together with the result from the dummy for the 19-day average price of the underlying, which yield a negative relationship, meaning that people tend to buy if the underlying is below that average, these results fit the negative feedback trading story.

The last variable in our logit model measures whether or not the underlying of the warrant is in the portfolio of the respective investor. Call warrants are more likely to be bought if the underlying is in the portfolio of an investor. This means they use these warrants to leverage their position in the underlying.

When we split the sample into purchases of call warrants on stock market indexes and single stocks ${ }^{14}$, we only find one structural difference in the two categories. Negative feedback trading is stronger and lasts longer for purchases in call warrants on indexes. While past returns of indexes negatively influence the buying decision for up to half a year, the turning point from negative to positive feedback trading for warrants on stocks is in one month returns.

\subsubsection{Put Purchases}

For buying behavior of individual investors in put warrants, the results of the logit regressions for warrants on all underlyings, on indexes, and on stocks are reported in Table 6. Here, the short-term returns of the underlyings are positively related to the dummy variable that is one if an investor buys a warrant and zero otherwise. This relation is reversed for returns that are longer ago. Since a put warrant loses value if the price of its underlying rises, the observed behavior is consistent with the short-term negative and long-term positive feedback trading in call warrants and stock purchases. By the division into buys of warrants on indexes and stocks, we observe in contrast to purchases in calls, that the negative feedback trading in stock warrants is dependent on past returns of a longer horizon. Just as for purchases in call warrants, the variance has a positive influence on the probability to buy put warrants. This is the case for puts on all underlyings, as well as indexes and stocks as underlying separately, while the influence on the buying decision in index warrants is stronger.

In contrast to call warrants, put warrants are likely to be purchased if the moneyness

\footnotetext{
${ }^{14}$ The decision to trade derivatives on indexes and stocks might differ, since an index cannot be held by the investors, as pointed out by Evnine and Rudd (1985). The latter is the reason for not including the dummy for the underlying in the portfolio in the logit regression for purchases of index warrants in Tables 5,6 , and 7 .
} 
is lower. The approaching or crossing of the strike price does have a positive influence on the buying decision, as it was shown for call warrants. Only for put purchases with stocks as underlying, does this effect not concern every category. Stock warrants are especially likely to be bought if the the price of the underlying reaches a price level slightly above the strike price. The maximum and minimum also influence the probability to buy puts positively. The fact that the influence of the minimum price is stronger than for the maximum price, as well as the fact that investors tend to buy puts when the price of the underlying is below its 19-day average is a bit confusing, as it seems to contradict the contrarian story. Further insights about the question of how important this relation is are discussed in the next section. Another interesting result is that investors are less prone to buy put warrants if they already hold the underlying in the portfolio. This is a further hint that hedging is not as important as conventional beliefs and textbooks on this topic often state.

\subsubsection{Call vs. Put Purchases}

As Grinblatt and Keloharju (2001b) state on page 607, they compare (in the absence of short selling possibilities) buy with sell transactions to circumvent the problem of a lack of information concerning the investment universe the investors have to choose from when making their purchase decision. But in comparing purchases and sales, one introduces another problem, because purchases and sales might be driven by different motives as mentioned before and broadly discussed in Barber and Odean (2007). The structure of the market for bank-issued warrants gives us the opportunity to circumvent this problem by comparing purchases in call and put warrants. As shown before, hedging does not play an important role in that market, so the purchase of a put is a speculation on falling prices of the underlying, i.e. a substitute for a short-sale of the underlying. Consequently, investors can speculate on rising or falling prices of the underlying by purchasing either call or put warrants for the same transaction costs.

In another logit regression, we regress the variables described above plus some other variables described later on a dummy variable that is on if somebody buys a call warrant and zero if a put warrant is purchased. Since there are unequal transactions from different investors, we cluster these in our regression, and report coefficients and robust p-values in Table 7. When considering the returns, we find the expected results given the literature 
and the results from Sections 4.1.1 and 4.1.2. It is more likely that investors buy call warrants than put warrants if the short-term past returns are negative. This dependency does not reverse until one looks back more than half a year, which is consistent with the literature on individual investors' behavior in the stock market. The results hold as well for warrants on indexes and stocks separately. That is different for the influence of the variance on the decision to buy calls or puts. While on aggregate investors seem to favor calls over puts if the variance is high, this relation disappears if we split our sample into warrants on indexes and stocks. A higher moneyness neither favors the purchase of calls nor of puts. The closeness of the price of the underlying to the strike price induces slightly more purchases in put warrants, but does not seem to have an influence on the decision to purchase calls or puts on stocks. The results for the maximum and minimum prices address the question raised in Section 4.1.2 whether the observed trading patterns are consistent with the negative feedback story for short horizons in past returns of the underlying. We find that call warrants are less likely to be purchased than put warrants if the price of the underlying is at its 19-day high, and more likely to be purchased if it is at its minimum price. These facts support the view that individual investors trade on negative feedback. The average price of the underlying does not influence the decision to purchase calls or puts, except for warrants on single stocks, where more calls are bought if the average price is above its mean. Not surprisingly, given Table 4 and the results stated above, the propensity to buy call warrants is higher than to purchase put warrant if the underlying is in the portfolio.

The format of our sample gives us the opportunity to include further interesting variables in our logit model. First, we show that investors buy call warrants with a slightly higher time to maturity than the put warrants have when they are purchased. Secondly, we include some variables concerning the repurchasing behavior of warrant investors. Besides the variables investigated by Barber, Odean, and Strahilevitz (2004), we generate some additional variables making use of the fact that the prices of warrants are dependent on the price of their underlying and that the warrants exhibit a finite lifespan. If a warrant approaches its maturity date, investors are forced to trade. To determine how big the effect is, we defined a dummy variable, maturity $[0 ;+5]$, that is one if a warrant is sold but not initially bought within 5 trading days to maturity. ${ }^{15}$ If an investor was

\footnotetext{
${ }^{15}$ This variable does not concern the buying but the selling decision. Consequently, it is ignored here but included in the logit regression in Section 4.2.3.
} 
forced to sell her warrant because the termination date was near, she might repurchase another warrant on the particular underlying with a longer time to maturity, thus we set repurchase_maturity to one if an investor sold a warrant within five days to maturity and repurchases another warrant on the same underlying in the next five trading days. Yet the situation where the warrant runs out of time is not the only case where some investors might be willing to switch to warrants on the same underlying but with different characteristics (e.g. time to maturity or strike price). Therefore we define the dummy repurchase $[-5 ; 0]$ which is 1 if the investor purchases a warrant and sold a warrant on the same underlying five trading days before. Additionally, we include a variable that is one if a warrant is repurchased if the investor experienced a realized gain in a warrant on the same underlying before (repurchase_gain_before). Another dummy is one if an investor purchases additional warrants in a sequential trade and the actual purchase price is lower than the price for the same warrant in the initial purchase of the round-trip trade (addpurchase_lost), testing whether investors follow the strategy to reduce the average purchase price. Anecdotal evidence proves this to be popular behavior among individual investors. The last variable is one if the price of the underlying decreased for call warrants or increased for put warrants since the investor closed a sequential trade in a warrant on the same underlying (repurchase_wrong ${ }^{u}$ ).

The most obvious results concerning the repurchasing variables are that the investors buy more call than put warrants if they have experienced a gain in another warrant on the same underlying, and that they buy more puts if the underlying went into the wrong direction after one sold a warrant on the same underlying before. Results for the other variables are mixed. Whereas more calls on indexes are repurchased if another call on the underlying was sold the 5 days before, less calls on stocks are bought if the near-term sale took place, because the warrant approached its maturity date. The likelihood of buying an additional call warrant on a stock compared to a put is higher if it has decreased in value since the first purchase of a round-trip trade.

\subsection{Determinants of the Selling Behavior}

As pointed out by Grinblatt and Keloharju (2001b), the investigation of the selling determinants is much more straight forward, because investors are restricted to the securities they currently hold in their portfolio. Thus, the set of alternatives is defined and fairly 
small in most cases. Grinblatt and Keloharju (2001b) define a variable as one if an investor sells a stock and 0 if he holds it on days where a sale took place, ignoring all other days. We define our dummy variable slightly differently. In our analysis, the dummy is one if an investor sells a warrant and zero on all days where the warrant is in the portfolio but not sold. That gives us the opportunity to analyze the time-series of the selling behavior of the broker clients at the individual level. ${ }^{16}$

For the decision about when to sell a warrant, we included some additional variables. Besides the dummy variable that measures if one sells a warrant because it will soon approach its maturity date (maturity $[0 ;+5]$ ), described in Section 4.1.3, we define two variables as candidates to measure the disposition effect for warrant investors. ${ }^{17}$ If we apply the simple measure of the disposition effect, comparing the holding periods of round-trip trades that end in a gain with the holding periods of those ending in a loss, as proposed by Shapira and Venezia (2001), we find strong evidence of the disposition effect. As shown in Table 8, the mean and median holding period for gain investments is significantly shorter than for loss investments. To get a more elaborate measure we define two additional variables. First, we define the variable $\operatorname{loss}^{u}$ that is equal to one if the underlying has lost in value since a warrant was purchased. We are looking at the price changes in the underlying because of the rationale presented in Section 4.1, and because we do not have price information for warrants on days where they were not traded in our data set. To see how closely our loss proxy captures the real losses, we compare our variable on days where our data set contains warrant price data, namely the days when a round-trip trade was closed and the actual return was realized. The correlation on these days is 0.9571 , which leads to the conclusion that our loss measure is fairly close to correctly approximating the losses over time. The second variable on the disposition effect is motivated by studies concerning the tax-loss effect and its influence on the disposition effect. ${ }^{18}$ They show that the disposition effect disappears or even reverses in December and attribute this to the fact that investors tend to sell losing investments in December because of tax advantages.

\footnotetext{
${ }^{16}$ The investors do not simultaneously hold call and put warrants on the same underlying. In 174 cases they hold call warrants on one underlying and put warrants on another one. If we exclude those cases, the results remain nearly unchanged.

${ }^{17}$ The disposition effect was empirically (e.g. Shefrin and Statman (1985), Odean (1998), Grinblatt and Keloharju (2001b), Shapira and Venezia (2001), Goetzmann and Massa (2004), and Feng and Seasholes (2005)) and experimentally (e.g. Weber and Camerer (1998) and Weber and Welfens (2006)) shown to exist for individuals.

${ }^{18}$ See, for examples, Odean (1998), Grinblatt and Keloharju (2004), Feng and Seasholes (2005), and Ivkovic, Poterba, and Weisbenner (2005).
} 
To investigate this fact in our analysis we include a dummy if the loss variable described above is one and if it is December $\left(\right.$ loss $^{u} \_$dec $)$.

\subsubsection{Call Sales}

From the coefficients of the return variables in Table 9, we see strong positive correlations between the past returns and the probability to sell a call warrant. This relation is positive (or insignificant) for all past returns, but decreases in strength the farther in the past those returns occured. This is in accordance with the results of the studies concerning the selling behavior, described in Section 2.1.2. As they reported, we find negative feedback trading not only for short-term, but also longer-term past returns. In contrast to Barber and Odean (2007), the variance does not influence the selling of call warrants positively. The propensity of investors to sell these warrants decreases if the variability of the underlying increases. In addition, the investors tend to sell warrants with higher moneyness. The approaching and crossing of the price of the underlying of the strike price increases the likelihood to sell calls, as do the underlyings when reaching a 19-day high or low, while the maximum price has a stronger influence. Call warrants are more likely to be sold if the price of the underlying is above its average, except for calls on indexes. All these results show, investors seem to rely on negative feedback trading when it comes to selling calls. Not surprisingly, the investors tend to sell warrants before the end of the lifespan of the warrants. This might be the case because selling the warrants on the secondary market is cheaper and more convenient than exercising the warrant. The latter would imply filling in a form announcing the exercise and waiting a few days until the underlying or the money from cash settlement ${ }^{19}$ is booked into the portfolio of the investor by the online broker.

In accordance with a large amount of literature, we also find strong evidence of the disposition effect within the group of individual investors in the market for bank-issued warrants. The chance that people sell their warrants is smaller if they have experienced a loss with the warrant, even after controlling for past returns of the underlying. The direction of the influence reverses (or at least become insignificant) in the last month of the year. This reversal of the disposition effect is (according to the authors mentioned above)

\footnotetext{
${ }^{19}$ Most of the stock warrants include cash settlement instead of delivery of the underlying. For index warrants, it is necessary since the index cannot be delivered.
} 
due to tax-motivated selling because losses can be asserted for taxation. In Germany, losses from trading in the warrants (and other securities) can offset the gains from all kinds of security transactions that would otherwise be taxed with the personal income tax rate.

\subsubsection{Put Sales}

Similar to the sales of call warrants, put warrants are more likely to be sold on negative feedback (see Table 10). For put sales, this implies that a negative relationship exists between the propensity to sell and past returns of the underlying. This effect can be attributed to the trading in put warrants on indexes. The selling decision of put warrants on stocks does not show this pattern. In contrast to the sales of calls and in accordance with the buying behavior in calls and puts, sales of puts on indexes and stocks are positively influenced by the variance of the past returns. Those warrants are more likely to be sold if the price of the underlying varies a lot. The modified moneyness does not have an effect on the selling decision, and the convergence of the price of the underlying and the strike price influences the propensity to sell puts positively, as it was the case in all trading categories. Whether the price of the underlying is above its 19-day high or not has a different dependency for put sales. If the price is at its maximum, investors tend to hold the warrants, at least in aggregate and for warrants on indexes. For stock warrants, the relation is positive just as it exists in the other trading categories. Also in accordance to the other findings is that the minimum price increases the selling probability of put warrants. These warrants tend to be sold if the underlying is below its 19-day average. As for call sales, investors sell more readily if the lifespan of the warrant is about to reach its expiry date. In addition, the evidence for the disposition effect and the tax-loss effect is existent for put sales. While investors tend to hold on to losing investments in general, they more readily sell their losing warrant investments in December.

\subsubsection{Call vs. Put Sales}

For sales of warrants, we apply the same methodology as in Section 4.1.3, meaning that a sale of a call warrant is coded as one and the sale of a put warrant is coded as zero. The results for coefficients and robust p-values from the logit regression with investor clusters are shown in Table 11. In accordance with the contrarian behavior in the short- 
run, investors tend to sell call warrants with a higher probability if the past returns of the underlyings are higher. For mid-term past returns, the relation is negative while it reverses again in the longer run; but the coefficients are much smaller for these dependencies. Variance influences call sales positively. The coefficients for the strike price dummies do not show a consistent picture with those coefficients that are significant being negative, meaning that the influence is stronger on the sales of puts. If the price of the underlying is at its maximum or above its average, call warrants are sold more readily while more puts are sold at the minimum prices of the underlying. Calls are sold with a longer time to maturity. By looking at the results for index warrants and stock warrants separately (Columns 3 and 4 of Table 11), one can see that the results are mainly driven by the warrants on indexes. The motives to sell calls and puts seem to be similar for stock warrants.

\section{Conclusion}

We analyze the trading behavior of individual investors in option-like securities, specifically bank-issued warrants, and thus expand the growing literature of investors' behavior towards a new kind of security. A unique data set from a large German online broker gives us the opportunity to analyze the trading behavior of 1,454 investors, making 89,958 transactions in 6,724 warrants on 397 underlyings.

Of special interest is the structure of the market for those warrants, that have payoff profiles identical to plain-vanilla options. Because put warrants gain value if the price of the underlying decreases, the purchase of a put warrant is some kind of "leveraged short-sale". That makes it possible to compare call with put purchases and call with put sales instead of purchases with sales ${ }^{20}$, circumventing the problems arising from possible different motives for the buying and selling decision for securities. In addition, we can study the transactions in the following four trading categories: (i) call purchases (ii) call sales, (iii) put purchases, and (iv) put sales. Furthermore, we are able to link the behavior of these investors in warrants to their actual stock portfolios.

The main results of our analysis are that investors follow similar negative feedback trading strategies, as measured by past returns of the underlying, in their warrant invest-

\footnotetext{
${ }^{20}$ See Grinblatt and Keloharju (2001b).
} 
ments; as do other individual investors on the stock market in the short-run. As similarly reported for the stock market, for past returns occurring longer ago, this behavior reverses to positive feedback trading for purchases whereas the contrarian behavior remains for sales. This behavior is consistent throughout all four categories, and also if we compare call and put purchases and call and put sales directly. We also show that trading is more likely if the price of the underlying reaches eye-catching levels, e.g. the strike price of the warrant or its high or low over a 19 day period. Repurchases of call warrants on the same underlying are more likely compared to put warrants if investors have experienced a gain with a warrant on that underlying before and less likely if the underlying has lost in value since the investor closed another warrant position in that underlying.

We find strong evidence for the disposition effect and tax-loss selling for call as well as put warrants. The disposition effect is measured in different ways. By looking at the stock portfolios of the investors, we can show that hedging is rare for these investors. In only 87 cases is the underlying in the portfolio if the investor purchases a put; compared to 2,201 times for call warrants. The probability to buy calls is positively related to the holding of the underlying in the portfolio, while the relation between put purchases and the portfolio holding of the underlying is negative. We do not find large differences in the trading behavior in warrants with indexes or with stocks as underlyings, except for the sales of puts where short-term past returns does not have an influence on the trading probability of warrants on single stocks.

Our analysis marks only a first step into the field of trading behavior of investors in markets for derivatives at the individual level. Especially for the interaction of investment behavior in derivatives, together with the trading behavior in the respective underlyings might be an insightful and promising field of future research to understand how people make their investment decisions. 


\section{References}

Badrinath, Swaminatha G. and Wilbur G. Lewellen (1991), "Evidence on Tax-Motivated Securities Trading Behavior," Journal of Finance, 46, 369-382.

Barber, Brad M. and Terrance Odean (2007), "All that Glitters: The Effect of Attention and News on the Buying Behavior of Individual and Institutional Investors," Review of Financial Studies, forthcoming.

Barber, Brad M., Terrance Odean and Michal Strahilevitz (2004), "Once Burned, Twice Shy: Naive Learning, Counterfactuals, and the Repurchase of Stocks Previously Sold," Working Paper.

Barber, Brad M., Terrance Odean and Ning Zhu (2003), "Systematic Noise," Working Paper.

Bauer, Rob, Mathijs Cosemans and Piet Eichholtz (2007), "The Performance and Persistence of Individual Investors: Rational Agents or Tulip Maniacs?," Working Paper.

Chen, Gong-Meng, Kenneth A. Kim, John R. Nofsinger and Oliver M. Rui (2005), "Behavior and Performance of Emerging Market Investors: Evidence from China," Working Paper.

Choe, Hyuk, Bong-Chan Kho and Rene Stulz (1999), "Do Foreign Investors Destabilize stock markets? The Korean Experience in 1997," Journal of Finance, 54, 227-264.

Cohn, Richard A., Wilbur G. Lewellen, Ronald C. Lease and Gary G. Schlarbaum (1975), "Individual Investor Risk Aversion and Investment Portfolio Composition," Journal of Finance, 30, 605-620.

DDI (2007), "DDI Depesche," Deutsches Derivate Institut e.V., January 2007.

Dorn, Daniel, Gur Huberman and Paul Sengmueller (2007), "Correlated Trading and Returns," Journal of Finance, forthcoming.

Evnine, Jeremy and Andrew Rudd (1985), "Index Option: The Early Evidence," Journal of Finance, 40, 743-756.

Feng, Lei and Mark Seasholes (2005), "Do Investor Sophistication and Trading Experience Eliminate Behavioral Biases in Financial Markets?," Review of Finance, 9, 305-351.

Glaser, Markus and Philipp Schmitz (2007), "Privatinvestoren am Optionsscheinmarkt," Zeitschrift für Bankrecht und Bankwirtschaft, 19, 214-230.

Goetzmann, William and Massimo Massa (2004), "Disposition Matters: Volume, Volatility and Price Impact Of Behavioural Bias," Working Paper. 
Griffin, John M., Jeffrey H. Harris and Selim Topaloglu (2003), "The Dynamics of Institutional and Individual Trading," Journal of Finance, 58, 2285-2320.

Grinblatt, Mark and Matti Keloharju (2000), "The Investment Behavior and Performance of Various Investor Types: A Study of Finland's Unique Data Set," Journal of Financial Economics, 55 .

Grinblatt, Mark and Matti Keloharju (2001a), "How Distance, Language, and Culture Influences Stockholdings and Trades," Journal of Finance, 56, 1053-1073.

Grinblatt, Mark and Matti Keloharju (2001b), "What Makes Investors Trade?," Journal of Finance, 56, 589-616.

Grinblatt, Mark and Matti Keloharju (2004), "Tax-Loss Reading and Wash Sales," Journal of Financial Economics, 71.

Heath, Chip, Steven Huddart and Mark Lang (1999), "Psychological Factors and Stock Option Exercise," Quarterly Journal of Economics, 114, 601-627.

Ivkovic, Zoran, James Poterba and Scott Weisbenner (2005), "Tax-Motivated Trading by Individual Investors," Working Paper.

Jackson, Andrew (2003), "The Aggregate Behavior of Individual Investors," Working Paper.

Kim, Kenneth A. and John R. Nofsinger (2002), "The Behavior and Performance of Individual Investors in Japan," Working Paper.

Klotz, Antonie (2004), "Wer sind die neuen Stars?," Börse online, 17, 14-20.

Kumar, Alok and Ravi Dhar (2002), "A Non-Random Walk Down the Main Street: Impact of Price Trends on Trading Decisions of Individual Investors," Working Paper.

Lakonishok, Josef, Inmoo Lee, Neil D. Pearson and Allen M. Poteshmann (2007), "Option Market Aktivity," Review of Financial Studies, 20, 813-857.

Lease, Ronald C., Wilbur G. Lewellen and Gary G. Schlarbaum (1974), "The Individual Investor: Attributes and Attitudes," Journal of Finance, 29, 413-433.

Lewellen, Wilbur G., Ronald C. Lease and Gary G. Schlarbaum (1977), "Patterns of Investment Strategy and Behavior Among Individual Investors," Journal of Business, 50, 296-333.

Odean, Terrance (1998), "Are Investors Reluctant to Realize Their Losses?," Journal of Finance, 53, 1775-1798. 
Odean, Terrance (1999), "Do Investors Trade Too Much?," American Economic Review, 89, 1279-1298.

Poteshman, Allen M. and Vitaly Serbin (2003), "Clearly Irrational Financial Market Behavior: Evidence from the Early Exercise of Exchange Traded Stock Options," Journal of Finance, 58, 37-70.

Schlarbaum, Gary G., Wilbur G. Lewellen and Ronald C. Lease (1978a), "The CommonStock-Portfolio Performance Record of Individual Investors: 1964-70," Journal of Finance, 33, 429-441.

Schlarbaum, Gary G., Wilbur G. Lewellen and Ronald C. Lease (1978b), "Realized Returns on Common Stock Investments: The Experience of Individual Investors," Journal of Business, 51, 299-325.

Schmitz, Philipp, Markus Glaser and Martin Weber (2007), "Individual Investor Sentiment and Stock Returns - What Do We Learn from Warrant Traders?,"Working Paper.

Shapira, Zur and Itzhak Venezia (2001), "Patterns of Behavior of Professionally Managed and Independent Investors," Journal of Banking and Finance, 25, 1573-1587.

Shefrin, Hersh and Meir Statman (1985), "The Disposition to Sell Winners too Early and Ride Losers too Long: Theory and evidence," Journal of Finance, 40, 777-790.

Weber, Martin and Colin Camerer (1998), "The Disposition Effect in Securities Trading: An Experimental Analysis," Journal of Economic Behavior $\&$ Organization, 33, 167184.

Weber, Martin and Frank Welfens (2006), "An Individual Level Analysis of the Disposition Effect: Empirical and Experimental Evidence," Working Paper. 


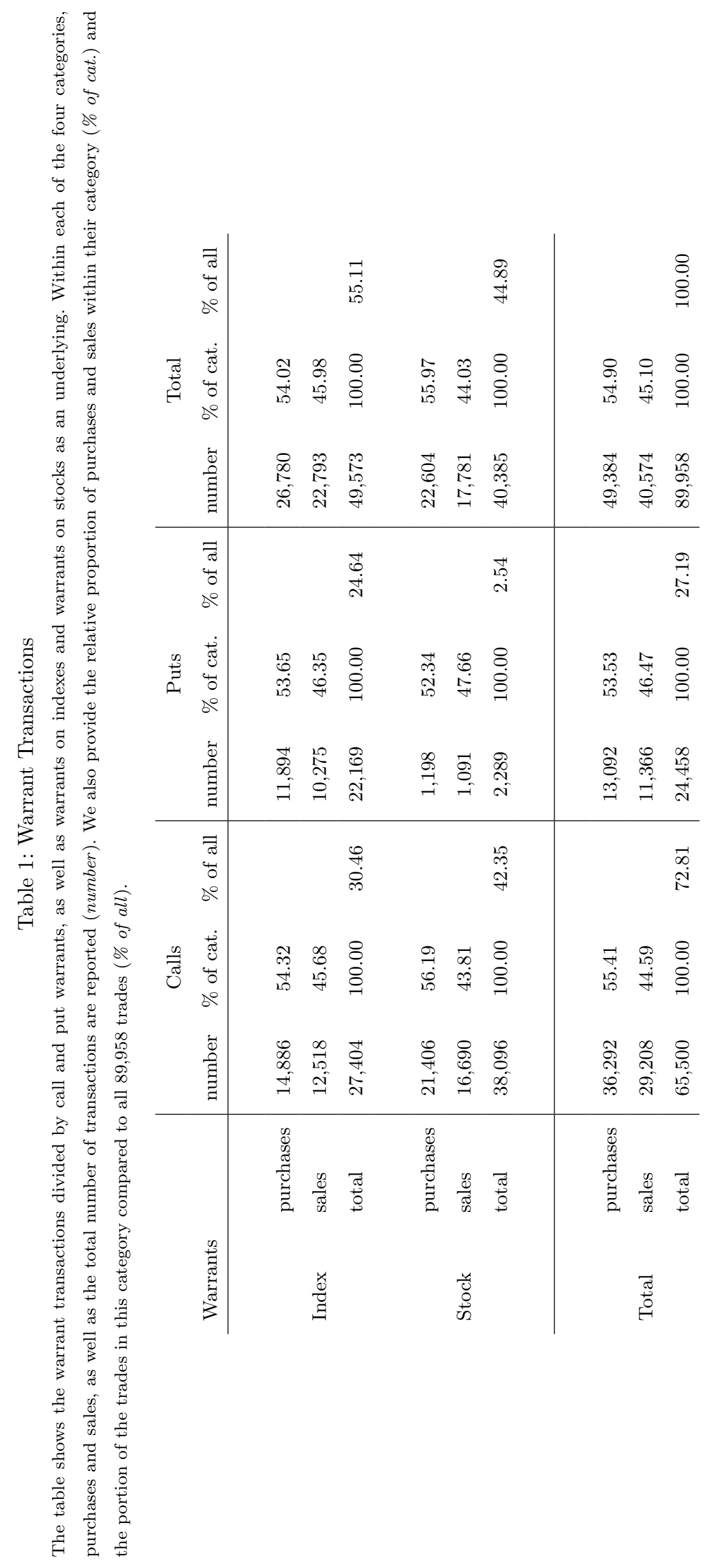


Table 2: The Five Most Traded Index and Stock Underlyings

When counting the most traded underlyings, we summed up all transactions in different warrants on that underlying. The column transactions shows how many transactions took place within warrants on the underlying mentioned in the columns index and stock. The column \% of all gives the portion of trades in warrants on the particular underlying compared to all 89,958 trades.

\begin{tabular}{lcc|lcc}
\multicolumn{2}{c|}{$\begin{array}{c}\text { Indexes (17 underlyings) } \\
\text { index }\end{array}$} & \multicolumn{3}{c}{ Stocks (380 underlyings) } \\
\hline transactions & $\%$ of all & \multicolumn{1}{c}{ stock } & transactions & $\%$ of all \\
\hline DAX 30 & 36,734 & 40.83 & Commerzbank & 2,689 & 2.99 \\
S\&P 500 & 3,150 & 3.50 & SAP & 1,804 & 2.01 \\
Dow Jones 30 & 2,355 & 2.62 & Deutsche Bank & 1,612 & 1.79 \\
Nasdaq 100 & 2,282 & 2.54 & VW & 1,491 & 1.66 \\
Nikkei 225 & 1,634 & 1.82 & Siemens & 1,394 & 1.55
\end{tabular}


Table 3: Descriptive Statistics

This table reports descriptive statistics about investors in the market for bank-issued warrants. Data in Panel A is derived from the transactions in the warrant market, data in Panel B is derived from transactions in the stock market, and in Panel C self-reported demographic information as well as information about investors' strategies is given. Volumes are in euros, returns and standard deviation are in percentages, time is measured in trading days, age is in years since birth at the beginning of our sample period, and experience is measured in years. The last four rows are dummy variables.

\begin{tabular}{l|r|rrrrrr} 
& obs. & mean & std.dev. & median & min. & max. \\
\hline \multicolumn{2}{c}{ Panel A: warrant portfolio } & & & \\
\hline number of warrant transactions & 1,454 & 54.98 & 122.14 & 18 & 1 & 1,461 \\
return on warrant transactions & 1,454 & 0.012 & 0.560 & -0.008 & -1 & 8.121 \\
average holding period of warrants & 1,454 & 68.51 & 77.68 & 43 & 0 & 767.81 \\
average warrant trading volume & 1,454 & 3,101 & 6,542 & 1,723 & 0 & 190,130 \\
average time to maturity & 1,454 & 109.73 & 95 & 108.35 & 0 & 1,046 \\
\hline \multicolumn{2}{l}{ Panel B: stock portfolio } & & & \\
\hline number of stock transactions & 1,413 & 137.12 & 224.97 & 74 & 0 & 2,838 \\
average number of stocks in portfolio & 1,413 & 7.05 & 6.13 & 5 & 1 & 48 \\
average portfolio volume & 1,413 & 32,249 & 57,807 & 14,743 & 4 & 828,423 \\
monthly return of stock portfolio & 1,324 & 0.004 & 0.026 & 0.004 & -0.160 & 0.197 \\
monthly STD of stock portfolio & 1,324 & 0.143 & 0.074 & 0.124 & 0.031 & 0.665 \\
\hline \multicolumn{1}{c|}{ Panel C: demographic and strategy information } & & & \\
\hline
\end{tabular}


Table 4: Warrant Purchases when the Underlying is in the Portfolio This table reports the number of purchases of warrants if the underlying was in the portfolio of the respective investor. The number is given for all underlyings and separately for call and put warrants. We also report the ratio of purchases when the underlying is in the portfolio, to the total purchases as well as to stock warrant purchases only.

\begin{tabular}{l|c|cc} 
& all & calls & puts \\
\hline purchases if underlying in portfolio & 2,288 & 2,201 & 87 \\
\hline \% of total warrant purchases & $4.63 \%$ & $6.06 \%$ & $0.66 \%$ \\
total warrant purchases & 49,384 & 36,292 & 13,092 \\
\hline \% of stock warrant purchases & $10.12 \%$ & $10.28 \%$ & $7.26 \%$ \\
stock warrant purchases & 22,604 & 21,406 & 1,198
\end{tabular}


Table 5: Call Purchases

This table reports coefficients and robust p-values for a logit regression. The dependent variable is a dummy that is 1 if an investor purchases a specific call warrant on a trading day, and 0 otherwise for trading days on which this specific warrant is tradeable. We do this for every warrant a specific investor traded at least once during our sample period. A $d_{-}$in front of the variable name indicates that the respective variable is a dummy variable. $* * *(* *, *)$ indicates significance on the $1 \%$ $(5 \%, 10 \%)$ level.

\begin{tabular}{|c|c|c|c|c|c|c|}
\hline & \multicolumn{2}{|c|}{ all underlyings } & \multicolumn{2}{|c|}{ indexes } & \multicolumn{2}{|c|}{ stocks } \\
\hline & coef. & p-value & coef. & p-value & coef. & $\mathrm{p}$-value \\
\hline $\operatorname{ret}^{u}[0]$ & $-2.526^{* * *}$ & $(0.000)$ & $-9.782^{* * *}$ & $(0.000)$ & $-2.291^{* * *}$ & $(0.000)$ \\
\hline $\operatorname{ret}^{u}[1]$ & $-1.833^{* * *}$ & $(0.000)$ & $-5.395^{* * *}$ & $(0.000)$ & $-1.808^{* * *}$ & $(0.000)$ \\
\hline $\operatorname{ret}^{u}[2]$ & $-0.747^{* * *}$ & $(0.000)$ & $-2.614^{* * *}$ & $(0.000)$ & $-0.905^{* * *}$ & $(0.000)$ \\
\hline $\operatorname{ret}^{u}[3]$ & -0.163 & $(0.431)$ & $-1.713^{* * *}$ & $(0.003)$ & -0.283 & $(0.207)$ \\
\hline $\operatorname{ret}^{u}[4]$ & 0.222 & $(0.270)$ & -0.315 & $(0.585)$ & 0.050 & $(0.820)$ \\
\hline $\operatorname{ret}^{u}[-19 ;-5]$ & $0.421^{* * *}$ & $(0.000)$ & -0.090 & $(0.616)$ & $0.390^{* * *}$ & $(0.000)$ \\
\hline $\operatorname{ret}^{u}[-39 ;-20]$ & 0.057 & $(0.162)$ & $-0.892^{* * *}$ & $(0.000)$ & $0.197^{* * *}$ & $(0.000)$ \\
\hline $\operatorname{ret}^{u}[-59 ;-40]$ & $0.109^{* * *}$ & $(0.010)$ & -0.089 & $(0.513)$ & $0.173^{* * *}$ & $(0.000)$ \\
\hline $\operatorname{ret}^{u}[-119 ;-60]$ & $0.138^{* * *}$ & $(0.000)$ & $-1.005^{* * *}$ & $(0.000)$ & $0.237^{* * *}$ & $(0.000)$ \\
\hline $\operatorname{ret}^{u}[-179 ;-120]$ & -0.025 & $(0.218)$ & $-0.881^{* * *}$ & $(0.000)$ & $0.055^{* * *}$ & $(0.005)$ \\
\hline $\operatorname{ret}^{u}[-239 ;-180]$ & $0.155^{* * *}$ & $(0.000)$ & $0.307 * * *$ & $(0.000)$ & $0.138^{* * *}$ & $(0.000)$ \\
\hline$\left(a v g \_r e t^{2}\right)^{u}[-59 ; 0]$ & $21.812^{* * *}$ & $(0.000)$ & 32.041 & $(0.379)$ & $35.634^{* * *}$ & $(0.000)$ \\
\hline mod. moneyness & -0.003 & $(0.212)$ & $-0.007^{* *}$ & $(0.029)$ & -0.003 & $(0.367)$ \\
\hline d_near_strike_right & $0.802^{* * *}$ & $(0.000)$ & $0.993^{* * *}$ & $(0.000)$ & $0.634^{* * *}$ & $(0.000)$ \\
\hline$d \_n e a r \_s t r i k e \_w r o n g$ & $0.788^{* * *}$ & $(0.000)$ & $0.863^{* * *}$ & $(0.000)$ & $0.604^{* * *}$ & $(0.000)$ \\
\hline d_cross_strike_right & $0.887^{* * *}$ & $(0.000)$ & $1.173^{* * *}$ & $(0.000)$ & $0.487^{* * *}$ & $(0.000)$ \\
\hline d_cross_strike_wrong & $0.913^{* * *}$ & $(0.000)$ & $1.057^{* * *}$ & $(0.000)$ & $0.466^{* * *}$ & $(0.000)$ \\
\hline$d \_\max ^{u}[-19 ;-1]$ & $0.186^{* * *}$ & $(0.000)$ & $0.058^{*}$ & $(0.067)$ & $0.331^{* * *}$ & $(0.000)$ \\
\hline$d_{-} \min ^{u}[-19 ;-1]$ & $0.385^{* * *}$ & $(0.000)$ & $0.134^{* * *}$ & $(0.000)$ & $0.402^{* * *}$ & $(0.000)$ \\
\hline$d_{-} a v g^{u}[-19 ;-1]$ & $-0.194^{* * *}$ & $(0.000)$ & $-0.197 * * *$ & $(0.000)$ & $-0.142^{* * *}$ & $(0.000)$ \\
\hline d_underlying_portfolio & $0.218^{* * *}$ & $(0.000)$ & - & - & $0.295^{* * *}$ & $(0.000)$ \\
\hline cons. & $-5.388^{* * *}$ & $(0.000)$ & $-5.110^{* * *}$ & $(0.000)$ & $-5.552^{* * *}$ & $(0.000)$ \\
\hline pseudo $R^{2}$ & \multicolumn{2}{|c|}{0.010} & \multicolumn{2}{|c|}{0.021} & \multicolumn{2}{|c|}{0.009} \\
\hline obs. & \multicolumn{2}{|c|}{$5,823,510$} & \multicolumn{2}{|c|}{$1,892,622$} & \multicolumn{2}{|c|}{$3,930,888$} \\
\hline
\end{tabular}


Table 6: Put Purchases

This table reports coefficients and robust p-values for a logit regression. The dependent variable is a dummy that is 1 if an investor purchases a specific put warrant on a trading day, and 0 otherwise for trading days on which this specific warrant is tradeable. We do this for every warrant a specific investor traded at least once during our sample period. A $d_{-}$in front of the variable name indicates that the respective variable is a dummy variable. $* * *(* *, *)$ indicates significance on the $1 \%$ $(5 \%, 10 \%)$ level.

\begin{tabular}{|c|c|c|c|c|c|c|}
\hline & \multicolumn{2}{|c|}{ all underlyings } & \multicolumn{2}{|c|}{ indexes } & \multicolumn{2}{|c|}{ stocks } \\
\hline & coef. & $\mathrm{p}$-value & coef. & $\mathrm{p}$-value & coef. & $\mathrm{p}$-value \\
\hline$r e t^{u}[0]$ & $2.174^{* * *}$ & $(0.000)$ & $3.944^{* * *}$ & $(0.000)$ & $1.367^{* *}$ & $(0.012)$ \\
\hline $\operatorname{ret}^{u}[1]$ & $2.795^{* * *}$ & $(0.000)$ & $3.391^{* * *}$ & $(0.000)$ & $2.467^{* * *}$ & $(0.000)$ \\
\hline $\operatorname{ret}^{u}[2]$ & 0.507 & $(0.403)$ & $1.234^{*}$ & $(0.089)$ & -0.029 & $(0.979)$ \\
\hline $\operatorname{ret}^{u}[3]$ & 0.626 & $(0.272)$ & -0.088 & $(0.901)$ & $1.626^{* * *}$ & $(0.004)$ \\
\hline $\operatorname{ret}^{u}[4]$ & 0.247 & $(0.674)$ & -0.916 & $(0.189)$ & $2.058^{* * *}$ & $(0.000)$ \\
\hline $\operatorname{ret}^{u}[-19 ;-5]$ & 0.064 & $(0.731)$ & $-0.558^{* *}$ & $(0.013)$ & $1.283^{* * *}$ & $(0.000)$ \\
\hline $\operatorname{ret}^{u}[-39 ;-20]$ & 0.031 & $(0.812)$ & 0.075 & $(0.619)$ & 0.246 & $(0.259)$ \\
\hline $\operatorname{ret}^{u}[-59 ;-40]$ & 0.172 & $(0.142)$ & $0.394^{* * *}$ & $(0.008)$ & 0.059 & $(0.764)$ \\
\hline $\operatorname{ret}^{u}[-119 ;-60]$ & $-0.835^{* * *}$ & $(0.000)$ & $-1.107^{* * *}$ & $(0.000)$ & $-0.458^{* * *}$ & $(0.000)$ \\
\hline $\operatorname{ret}^{u}[-179 ;-120]$ & $-0.887^{* * *}$ & $(0.000)$ & $-1.618^{* * *}$ & $(0.000)$ & -0.128 & $(0.196)$ \\
\hline $\operatorname{ret}^{u}[-239 ;-180]$ & $-0.474^{* * *}$ & $(0.000)$ & $-0.979 * * *$ & $(0.000)$ & -0.086 & $(0.242)$ \\
\hline$\left(\text { avg_ret }^{2}\right)^{u}[-59 ; 0]$ & $12.761^{* *}$ & $(0.037)$ & $332.982^{* * *}$ & $(0.000)$ & $12.732^{*}$ & $(0.060)$ \\
\hline mod. moneyness & $-0.027 * * *$ & $(0.000)$ & $-0.021^{* * *}$ & $(0.000)$ & $-0.088^{* * *}$ & $(0.000)$ \\
\hline d_near_strike_right & $1.570^{* * *}$ & $(0.000)$ & $1.615^{* * *}$ & $(0.000)$ & $1.288^{* * *}$ & $(0.000)$ \\
\hline d_near_strike_wrong & $1.336^{* * *}$ & $(0.000)$ & $1.337^{* * *}$ & $(0.000)$ & 0.140 & $(0.786)$ \\
\hline d_cross_strike_right & $1.542^{* * *}$ & $(0.000)$ & $1.597^{* * *}$ & $(0.000)$ & 0.619 & $(0.108)$ \\
\hline d_cross_strike_wrong & $1.547^{* * *}$ & $(0.000)$ & $1.538^{* * *}$ & $(0.000)$ & $0.761^{*}$ & $(0.051)$ \\
\hline$d \_\max ^{u}[-19 ;-1]$ & $0.232^{* * *}$ & $(0.000)$ & $0.201^{* * *}$ & $(0.000)$ & $0.439 * * *$ & $(0.000)$ \\
\hline$d \_\min ^{u}[-19 ;-1]$ & $0.323^{* * *}$ & $(0.000)$ & $0.341^{* * *}$ & $(0.000)$ & $0.361^{* * *}$ & $(0.001)$ \\
\hline$d_{-} a v g^{u}[-19 ;-1]$ & $-0.339^{* * *}$ & $(0.000)$ & $-0.307^{* * *}$ & $(0.000)$ & $-0.557^{* * *}$ & $(0.000)$ \\
\hline d_underlying_portfolio & $-0.256^{* *}$ & $(0.020)$ & - & - & 0.025 & $(0.825)$ \\
\hline cons. & $-5.694^{* * *}$ & $(0.000)$ & $-5.668^{* * *}$ & $(0.000)$ & $-6.069^{* * *}$ & $(0.000)$ \\
\hline pseudo. $R^{2}$ & 0 . & & & & & \\
\hline obs. & 3,650 & & 3,074 & & 575 , & \\
\hline
\end{tabular}


Table 7: Call vs. Put Purchases

This table reports coefficients and robust p-values for a logit regression with clusters for the different investors. The dependent variable is a dummy that is 1 if an investor purchases a call warrant and 0 if an investor purchases a put warrant. A $d_{-}$in front of the variable name indicates that the respective variable is a dummy variable. $* * *(* *, *)$ indicates significance on the $1 \%(5 \%, 10 \%)$ level.

\begin{tabular}{|c|c|c|c|c|c|c|}
\hline & \multicolumn{2}{|c|}{ all underlyings } & \multicolumn{2}{|c|}{ indexes } & \multicolumn{2}{|c|}{ stocks } \\
\hline & coef. & $\mathrm{p}$-value & coef. & p-value & coef. & $\mathrm{p}$-value \\
\hline $\operatorname{ret}^{u}[0]$ & -1.528 & $(0.123)$ & $-7.789 * * *$ & $(0.000)$ & $-2.159^{* *}$ & $(0.040)$ \\
\hline $\operatorname{ret}^{u}[1]$ & $-2.099 * * *$ & $(0.007)$ & $-5.630^{* * *}$ & $(0.000)$ & $-3.952^{* * *}$ & $(0.000)$ \\
\hline $\operatorname{ret}^{u}[2]$ & 0.452 & $(0.551)$ & $-2.732^{* *}$ & $(0.013)$ & -1.076 & $(0.231)$ \\
\hline $\operatorname{ret}^{u}[3]$ & -0.253 & $(0.716)$ & $-1.709^{*}$ & $(0.095)$ & $-3.055^{* * *}$ & $(0.000)$ \\
\hline $\operatorname{ret}^{u}[4]$ & 1.023 & $(0.120)$ & 1.279 & $(0.167)$ & $-3.007^{* * *}$ & $(0.001)$ \\
\hline $\operatorname{ret}^{u}[-19 ;-5]$ & $0.527^{*}$ & $(0.075)$ & -0.010 & $(0.977)$ & $-1.526 * * *$ & $(0.000)$ \\
\hline $\operatorname{ret}^{u}[-39 ;-20]$ & $-0.789 * * *$ & $(0.000)$ & $-1.863^{* * *}$ & $(0.000)$ & $-0.536^{* *}$ & $(0.034)$ \\
\hline $\operatorname{ret}^{u}[-59 ;-40]$ & $-0.677^{* * *}$ & $(0.000)$ & $-1.229^{* * *}$ & $(0.000)$ & $-0.327^{*}$ & $(0.077)$ \\
\hline $\operatorname{ret}^{u}[-119 ;-60]$ & -0.155 & $(0.205)$ & $-1.082^{* * *}$ & $(0.000)$ & 0.157 & $(0.183)$ \\
\hline $\operatorname{ret}^{u}[-179 ;-120]$ & 0.134 & $(0.282)$ & -0.169 & $(0.418)$ & 0.003 & $(0.979)$ \\
\hline $\operatorname{ret}^{u}[-239 ;-180]$ & $0.498^{* * *}$ & $(0.000)$ & $0.403^{* *}$ & $(0.022)$ & $0.219^{* *}$ & $(0.016)$ \\
\hline$\left(a v g \_r e t^{2}\right)^{u}[-59 ; 0]$ & $607.294^{* * *}$ & $(0.000)$ & 69.632 & $(0.479)$ & -25.518 & $(0.210)$ \\
\hline mod. moneyness & 0.008 & $(0.239)$ & 0.022 & $(0.104)$ & -0.002 & $(0.547)$ \\
\hline d_near_strike_right & $-0.618^{* * *}$ & $(0.000)$ & $-0.387^{* * *}$ & $(0.006)$ & -0.518 & $(0.109)$ \\
\hline d_near_strike_wrong & -0.099 & $(0.366)$ & 0.179 & $(0.105)$ & 0.745 & $(0.150)$ \\
\hline d_cross_strike_right & $-0.381^{* * *}$ & $(0.000)$ & $-0.181^{*}$ & $(0.086)$ & -0.150 & $(0.683)$ \\
\hline d_cross_strike_wrong & $-0.271^{* * *}$ & $(0.006)$ & 0.025 & $(0.796)$ & -0.178 & $(0.645)$ \\
\hline$d \_m a x^{u}[-19 ;-1]$ & $-0.370^{* * *}$ & $(0.000)$ & $-0.225^{* * *}$ & $(0.000)$ & $-0.203^{*}$ & $(0.081)$ \\
\hline$d_{-} \min ^{u}[-19 ;-1]$ & $0.120^{* *}$ & $(0.025)$ & -0.056 & $(0.333)$ & $0.327^{* *}$ & $(0.016)$ \\
\hline d_avg $g^{u}[-19 ;-1]$ & -0.085 & $(0.167)$ & 0.008 & $(0.915)$ & $0.622^{* * *}$ & $(0.000)$ \\
\hline d_underlying_portfolio & $1.505^{* * *}$ & $(0.000)$ & - & - & 0.261 & $(0.295)$ \\
\hline time_to_maturity & $0.004^{* * *}$ & $(0.000)$ & $0.002^{* * *}$ & $(0.002)$ & $0.003^{* * *}$ & $(0.000)$ \\
\hline$d \_r e p u r c h a s e[-5 ; 0]$ & -0.053 & $(0.407)$ & $0.210^{* * *}$ & $(0.004)$ & 0.081 & $(0.666)$ \\
\hline$d \_r e p u r c h a s e \_m a t u r i t y[-5 ; 0]$ & 0.234 & $(0.288)$ & 0.215 & $(0.281)$ & $-1.531^{*}$ & $(0.051)$ \\
\hline d_repurchase_gain_before & $0.182^{* * *}$ & $(0.002)$ & $0.151^{* *}$ & $(0.013)$ & $0.987^{* * *}$ & $(0.000)$ \\
\hline d_addpurchase_lost & -0.007 & $(0.916)$ & -0.101 & $(0.139)$ & $0.763^{* * *}$ & $(0.000)$ \\
\hline 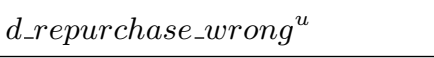 & $-0.557^{* * *}$ & $(0.000)$ & $-0.565^{* * *}$ & $(0.000)$ & -0.200 & $(0.291)$ \\
\hline cons. & 0.070 & $(0.476)$ & 0.046 & $(0.713)$ & $1.576^{* * *}$ & $(0.000)$ \\
\hline pseudo $R^{2}$ & 0.12 & & 0.0 & & & \\
\hline obs. & 42,0 & & 22,1 & & 19,9 & \\
\hline
\end{tabular}


Table 8: Holding Periods of Winning and Losing Warrant Investments

This table reports the average and median holding periods in trading days for warrant investments. Columns 3 and 4 report the holding periods dependent on whether the investment ended in a gain or a loss. The differences in the means and medians were tested with a t-test and a median test, respectively. The p-values are given in the last column.

\begin{tabular}{l|c|cc|cc} 
holding period & all & gain & loss & diff. & p-value \\
\hline mean & 33.4 & 25.43 & 43.32 & 17.89 & $<0.0001$ \\
median & 8 & 6 & 11 & 5 & $<0.0001$ \\
obs. & 28,393 & 15,747 & 12,646 & &
\end{tabular}


Table 9: Call Sales

This table reports coefficients and robust p-values for a logit regression. The dependent variable is a dummy that is 1 if an investor sells a specific call warrant and 0 when the investor holds the warrant in his portfolio without selling it. A $d_{-}$in front of the variable name indicates that the respective variable is a dummy variable. *** $(* *, *)$ indicates significance on the $1 \%(5 \%, 10 \%)$ level.

\begin{tabular}{|c|c|c|c|c|c|c|}
\hline & \multicolumn{2}{|c|}{ all underlyings } & \multicolumn{2}{|c|}{ indexes } & \multicolumn{2}{|c|}{ stocks } \\
\hline & coef. & $\mathrm{p}$-value & coef. & $\mathrm{p}$-value & coef. & $\mathrm{p}$-value \\
\hline $\operatorname{ret}^{u}[0]$ & $5.611^{* * *}$ & $(0.000)$ & $17.911^{* * *}$ & $(0.000)$ & $5.497^{* * *}$ & $(0.000)$ \\
\hline $\operatorname{ret}^{u}[1]$ & $4.407^{* * *}$ & $(0.000)$ & $11.484^{* * *}$ & $(0.000)$ & $4.748^{* * *}$ & $(0.000)$ \\
\hline $\operatorname{ret}^{u}[2]$ & $1.689^{* * *}$ & $(0.000)$ & $5.642^{* * *}$ & $(0.000)$ & $2.635^{* * *}$ & $(0.000)$ \\
\hline $\operatorname{ret}^{u}[3]$ & 0.537 & $(0.130)$ & $1.935^{*}$ & $(0.056)$ & $1.597^{* * *}$ & $(0.000)$ \\
\hline $\operatorname{ret}^{u}[4]$ & 0.324 & $(0.363)$ & $2.098^{* *}$ & $(0.046)$ & $1.387^{* * *}$ & $(0.000)$ \\
\hline $\operatorname{ret}^{u}[-19 ;-5]$ & $0.404^{* * *}$ & $(0.000)$ & $1.757^{* * *}$ & $(0.000)$ & $0.853^{* * *}$ & $(0.000)$ \\
\hline $\operatorname{ret}^{u}[-39 ;-20]$ & $0.581^{* * *}$ & $(0.000)$ & $1.890^{* * *}$ & $(0.000)$ & $0.792^{* * *}$ & $(0.000)$ \\
\hline $\operatorname{ret}^{u}[-59 ;-40]$ & $0.283^{* * *}$ & $(0.000)$ & $1.346^{* * *}$ & $(0.000)$ & $0.427^{* * *}$ & $(0.000)$ \\
\hline $\operatorname{ret}^{u}[-119 ;-60]$ & $0.136^{* * *}$ & $(0.000)$ & $0.359^{* * *}$ & $(0.003)$ & $0.196^{* * *}$ & $(0.000)$ \\
\hline $\operatorname{ret}^{u}[-179 ;-120]$ & -0.044 & $(0.154)$ & $-0.556^{* * *}$ & $(0.000)$ & $0.089^{* * *}$ & $(0.001)$ \\
\hline $\operatorname{ret}^{u}[-239 ;-180]$ & -0.003 & $(0.895)$ & $0.352^{* * *}$ & $(0.000)$ & 0.029 & $(0.260)$ \\
\hline$\left(\text { avg_ret }^{2}\right)^{u}[-59 ; 0]$ & $-104.121^{* * *}$ & $(0.000)$ & $-286.966^{* * *}$ & $(0.000)$ & $-53.538^{* * *}$ & $(0.000)$ \\
\hline mod. moneyness & $0.005^{* * *}$ & $(0.006)$ & $0.015^{* * *}$ & $(0.000)$ & $0.004^{*}$ & $(0.095)$ \\
\hline d_near_strike_right & $0.592^{* * *}$ & $(0.000)$ & $0.597^{* * *}$ & $(0.000)$ & 0.086 & $(0.574)$ \\
\hline$d_{-} n e a r \_s t r i k e \_w r o n g$ & $0.815^{* * *}$ & $(0.000)$ & $0.711^{* * *}$ & $(0.000)$ & $0.405^{* * *}$ & $(0.000)$ \\
\hline$d_{-} c r o s s_{-} s t r i k e_{-} r i g h t$ & $0.738^{* * *}$ & $(0.000)$ & $0.599 * * *$ & $(0.000)$ & $0.565^{* * *}$ & $(0.000)$ \\
\hline 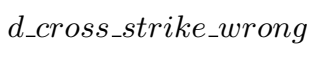 & $0.863^{* * *}$ & $(0.000)$ & $0.756^{* * *}$ & $(0.000)$ & $0.446^{* * *}$ & $(0.000)$ \\
\hline$d_{-} \max ^{u}[-19 ;-1]$ & $0.380 * * *$ & $(0.000)$ & $0.173^{* * *}$ & $(0.000)$ & $0.393^{* * *}$ & $(0.000)$ \\
\hline$d \_\min ^{u}[-19 ;-1]$ & $0.161^{* * *}$ & $(0.000)$ & $0.167^{* * *}$ & $(0.000)$ & $0.248^{* * *}$ & $(0.000)$ \\
\hline$d_{-} a v g^{u}[-19 ;-1]$ & $0.087^{* * *}$ & $(0.000)$ & 0.037 & $(0.220)$ & $0.066^{* * *}$ & $(0.003)$ \\
\hline$d_{-}$maturity $[0 ;+5]$ & $1.646^{* * *}$ & $(0.000)$ & $1.213^{* * *}$ & $(0.000)$ & $1.832^{* * *}$ & $(0.000)$ \\
\hline$d_{-} l o s s^{u}$ & $-0.632^{* * *}$ & $(0.000)$ & $-0.460^{* * *}$ & $(0.000)$ & $-0.691^{* * *}$ & $(0.000)$ \\
\hline$d_{-} l o s s^{u}{ }_{\text {dec }}$ & $0.177^{* * *}$ & $(0.000)$ & 0.021 & $(0.728)$ & $0.228^{* * *}$ & $(0.000)$ \\
\hline cons. & $-3.978^{* * *}$ & $(0.000)$ & $-3.704^{* * *}$ & $(0.000)$ & $-4.360^{* * *}$ & $(0.000)$ \\
\hline pseudo $R^{2}$ & 0.02 & & 0.02 & & 0.0 & \\
\hline obs. & 1,253 & & 270,9 & & 982 & \\
\hline
\end{tabular}


Table 10: Put Sales

This table reports coefficients and robust p-values for a logit regression. The dependent variable is a dummy that is 1 if an investor sells a specific put warrant and 0 when the investor holds the warrant in his portfolio without selling it. A $d_{-}$in front of the variable name indicates that the respective variable is a dummy variable. $* * *(* *, *)$ indicates significance on the $1 \%(5 \%, 10 \%)$ level.

\begin{tabular}{|c|c|c|c|c|c|c|}
\hline & \multicolumn{2}{|c|}{ all underlyings } & \multicolumn{2}{|c|}{ indexes } & \multicolumn{2}{|c|}{ stocks } \\
\hline & coef. & $\mathrm{p}$-value & coef. & $\mathrm{p}$-value & coef. & $\mathrm{p}$-value \\
\hline $\operatorname{ret}^{u}[0]$ & $-2.810^{* * *}$ & $(0.000)$ & $-6.754^{* * *}$ & $(0.000)$ & -0.124 & $(0.906)$ \\
\hline $\operatorname{ret}^{u}[1]$ & $-4.847^{* * *}$ & $(0.000)$ & $-9.456^{* * *}$ & $(0.000)$ & 0.317 & $(0.735)$ \\
\hline $\operatorname{ret}^{u}[2]$ & $-1.729 * * *$ & $(0.003)$ & $-4.331^{* * *}$ & $(0.000)$ & 0.663 & $(0.447)$ \\
\hline $\operatorname{ret}^{u}[3]$ & $-1.316^{* *}$ & $(0.023)$ & $-3.141^{* * *}$ & $(0.000)$ & 0.512 & $(0.573)$ \\
\hline $\operatorname{ret}^{u}[4]$ & -0.831 & $(0.137)$ & $-2.058 * * *$ & $(0.005)$ & 0.392 & $(0.650)$ \\
\hline $\operatorname{ret}^{u}[-19 ;-5]$ & -0.017 & $(0.924)$ & $-0.493^{* *}$ & $(0.036)$ & $0.768^{* * *}$ & $(0.002)$ \\
\hline $\operatorname{ret}^{u}[-39 ;-20]$ & -0.109 & $(0.374)$ & $-0.391^{* *}$ & $(0.012)$ & $0.334^{*}$ & $(0.070)$ \\
\hline $\operatorname{ret}^{u}[-59 ;-40]$ & -0.111 & $(0.386)$ & 0.037 & $(0.823)$ & -0.150 & $(0.453)$ \\
\hline $\operatorname{ret}^{u}[-119 ;-60]$ & $-0.566 * * *$ & $(0.000)$ & $-0.876^{* * *}$ & $(0.000)$ & $-0.266^{* * *}$ & $(0.003)$ \\
\hline $\operatorname{ret}^{u}[-179 ;-120]$ & $-0.539 * * *$ & $(0.000)$ & $-0.739 * * *$ & $(0.000)$ & $-0.433^{* * *}$ & $(0.000)$ \\
\hline $\operatorname{ret}^{u}[-239 ;-180]$ & $-0.138^{* *}$ & $(0.026)$ & -0.085 & $(0.384)$ & 0.022 & $(0.808)$ \\
\hline$\left(\text { avg_ret }{ }^{2}\right)^{u}[-59 ; 0]$ & 5.830 & $(0.737)$ & $407.754^{* * *}$ & $(0.000)$ & $157.442^{* * *}$ & $(0.000)$ \\
\hline mod. moneyness & -0.000 & $(0.947)$ & 0.013 & $(0.131)$ & -0.019 & $(0.560)$ \\
\hline d_near_strike_right & $0.584^{* * *}$ & $(0.000)$ & $0.501^{* * *}$ & $(0.000)$ & 0.360 & $(0.324)$ \\
\hline$d_{-} n e a r \_s t r i k e \_w r o n g$ & $0.493^{* * *}$ & $(0.000)$ & $0.380^{* * *}$ & $(0.000)$ & $1.185^{* * *}$ & $(0.002)$ \\
\hline d_cross_strike_right & $0.826^{* * *}$ & $(0.000)$ & $0.715^{* * *}$ & $(0.000)$ & $1.083^{* * *}$ & $(0.000)$ \\
\hline d_cross_strike_wrong & $0.702^{* * *}$ & $(0.000)$ & $0.691^{* * *}$ & $(0.000)$ & -0.768 & $(0.298)$ \\
\hline$d_{-} \max ^{u}[-19 ;-1]$ & $-0.100^{* * *}$ & $(0.007)$ & $-0.072^{*}$ & $(0.070)$ & $0.311^{* *}$ & $(0.014)$ \\
\hline$d_{-} \min ^{u}[-19 ;-1]$ & $0.319^{* * *}$ & $(0.000)$ & $0.152^{* * *}$ & $(0.000)$ & $0.316^{* * *}$ & $(0.006)$ \\
\hline$d \_a v g^{u}[-19 ;-1]$ & $-0.170 * * *$ & $(0.000)$ & $-0.130^{* * *}$ & $(0.000)$ & $-0.336^{* * *}$ & $(0.000)$ \\
\hline$d_{-}$maturity $[0 ;+5]$ & $1.111^{* * *}$ & $(0.000)$ & $1.094^{* * *}$ & $(0.000)$ & $1.452^{* * *}$ & $(0.000)$ \\
\hline$d_{-} l_{\text {loss }}^{u}$ & $-0.737^{* * *}$ & $(0.000)$ & $-0.747^{* * *}$ & $(0.000)$ & $-0.657^{* * *}$ & $(0.000)$ \\
\hline$d_{-} l o s s^{u}{ }_{-} d e c$ & $0.231^{* * *}$ & $(0.000)$ & $0.225^{* * *}$ & $(0.001)$ & -0.139 & $(0.500)$ \\
\hline cons. & $-2.678 * * *$ & $(0.000)$ & $-2.682^{* * *}$ & $(0.000)$ & $-3.506^{* * *}$ & $(0.000)$ \\
\hline pseudo $R^{2}$ & 0.0 & & 0.0 & & & \\
\hline obs. & 218 & & 179 & & 38,6 & \\
\hline
\end{tabular}


Table 11: Call vs. Put Sales

This table reports coefficients and robust p-values for a logit regression with clusters for the different investors. The dependent variable is a dummy that is 1 if an investor sells a call warrant and 0 if an investor sells a put warrant. A $d_{-}$in front of the variable name indicates that the respective variable is a dummy variable. $* * *(* *, *)$ indicates significance on the $1 \%(5 \%$, $10 \%$ ) level.

\begin{tabular}{|c|c|c|c|c|c|c|}
\hline & \multicolumn{2}{|c|}{ all underlyings } & \multicolumn{2}{|c|}{ indexes } & \multicolumn{2}{|c|}{ stocks } \\
\hline & coef. & p-value & coef. & $\mathrm{p}$-value & coef. & $\mathrm{p}$-value \\
\hline $\operatorname{ret}^{u}[0]$ & $6.724^{* * *}$ & $(0.000)$ & $11.589^{* * *}$ & $(0.000)$ & 0.934 & $(0.363)$ \\
\hline $\operatorname{ret}^{u}[1]$ & $7.148^{* * *}$ & $(0.000)$ & $9.610^{* * *}$ & $(0.000)$ & 1.096 & $(0.271)$ \\
\hline $\operatorname{ret}^{u}[2]$ & $2.855^{* * *}$ & $(0.001)$ & $3.101^{* *}$ & $(0.021)$ & -0.841 & $(0.352)$ \\
\hline $\operatorname{ret}^{u}[3]$ & $1.387^{*}$ & $(0.076)$ & 0.738 & $(0.522)$ & $-2.090^{* *}$ & $(0.046)$ \\
\hline $\operatorname{ret}^{u}[4]$ & $1.436^{*}$ & $(0.065)$ & -0.676 & $(0.543)$ & -0.610 & $(0.574)$ \\
\hline $\operatorname{ret}^{u}[-19 ;-5]$ & 0.329 & $(0.309)$ & -0.163 & $(0.679)$ & $-1.181^{* * *}$ & $(0.001)$ \\
\hline $\operatorname{ret}^{u}[-39 ;-20]$ & $-0.521^{* *}$ & $(0.015)$ & $-1.588^{* * *}$ & $(0.000)$ & $-0.434^{*}$ & $(0.075)$ \\
\hline $\operatorname{ret}^{u}[-59 ;-40]$ & $-0.730 * * *$ & $(0.000)$ & $-1.950 * * *$ & $(0.000)$ & -0.155 & $(0.494)$ \\
\hline $\operatorname{ret}^{u}[-119 ;-60]$ & $-0.460^{* * *}$ & $(0.000)$ & $-1.461^{* * *}$ & $(0.000)$ & -0.022 & $(0.855)$ \\
\hline $\operatorname{ret}^{u}[-179 ;-120]$ & -0.064 & $(0.529)$ & $-0.777^{* * *}$ & $(0.000)$ & -0.011 & $(0.921)$ \\
\hline $\operatorname{ret}^{u}[-239 ;-180]$ & $0.392^{* * *}$ & $(0.000)$ & 0.145 & $(0.417)$ & 0.049 & $(0.602)$ \\
\hline$\left(\text { avg_ret } t^{2}\right)^{u}[-59 ; 0]$ & $613.566^{* * *}$ & $(0.000)$ & 63.965 & $(0.499)$ & $-43.070^{*}$ & $(0.062)$ \\
\hline mod. moneyness & $0.019^{*}$ & $(0.050)$ & 0.012 & $(0.174)$ & -0.001 & $(0.861)$ \\
\hline d_near_strike_right & $-0.661^{* * *}$ & $(0.000)$ & $-0.243^{*}$ & $(0.053)$ & -0.589 & $(0.157)$ \\
\hline d_near_strike_wrong & 0.077 & $(0.505)$ & $0.201^{*}$ & $(0.092)$ & -0.235 & $(0.571)$ \\
\hline d_cross_strike_right & $-0.594^{* * *}$ & $(0.000)$ & $-0.271^{* *}$ & $(0.012)$ & $-0.919 * * *$ & $(0.002)$ \\
\hline d_cross_strike_wrong & -0.100 & $(0.300)$ & 0.029 & $(0.780)$ & 0.687 & $(0.224)$ \\
\hline$d \_\max ^{u}[-19 ;-1]$ & $0.152^{* * *}$ & $(0.002)$ & $0.246^{* * *}$ & $(0.000)$ & 0.012 & $(0.931)$ \\
\hline$d \_\min ^{u}[-19 ;-1]$ & $-0.131^{* *}$ & $(0.046)$ & -0.104 & $(0.182)$ & 0.112 & $(0.434)$ \\
\hline$d_{-} a v g^{u}[-19 ;-1]$ & $0.124^{* * *}$ & $(0.010)$ & 0.094 & $(0.100)$ & $0.942^{* * *}$ & $(0.000)$ \\
\hline time_to_maturity & $0.003^{* * *}$ & $(0.000)$ & 0.001 & $(0.147)$ & $0.002^{* * *}$ & $(0.000)$ \\
\hline cons. & $-0.150^{* *}$ & $(0.035)$ & 0.049 & $(0.587)$ & $1.699 * * *$ & $(0.000)$ \\
\hline pseudo $R^{2}$ & \multicolumn{2}{|c|}{0.122} & \multicolumn{2}{|c|}{0.056} & \multicolumn{2}{|c|}{0.051} \\
\hline obs. & \multicolumn{2}{|c|}{28,312} & \multicolumn{2}{|c|}{15,007} & \multicolumn{2}{|c|}{13,305} \\
\hline
\end{tabular}

